\title{
WARSZAWSKIE ŚRODOWISKO HISTORYKÓW HISTORIOGRAFII ZE SZCZEGÓLNYM UWZGLĘDNIENIEM UCZONYCH ZWIAZZANYCH Z INSTYTUTEM HISTORII POLSKIE] AKADEMII NAUK
}

\section{ABSTRACT}

THE WARSAW GROUP OF HISTORIANS OF HISTORIOGRAPHY WITH PARTICULAR EMPHASIS ON SCHOLARS WORKING IN THE INSTITUTE OF HISTORY OF THE POLISH ACADEMY OF SCIENCES

The development of the history of historiography in Poland was inspired by Marceli Handelsman, a professor at the Warsaw University in 1915-1939. After World War II, his students Marian Henryk Serejski and later Andrzej Feliks Grabski and Andrzej Wierzbicki - employees of the Institute of History of the Polish Academy of Sciences in Warsaw - developed research describing the impact of contemporary culture, current beliefs and political trends on historical research. Today, in the Warsaw group of historians, that research work is continued by Zbigniew Romek and Marcin Wolniewicz.

\section{KEYWORDS:}


Większość współczesnych historyków zgodnie stwierdza, że rozwój historii historiografii jako wyspecjalizowanej dziedziny badań nad przeszłością miał miejsce w Polsce dopiero po II wojnie światowej. Niewątpliwie prawdą jest także to, że refleksja nad historią historiografii pojawiła się u nas już od XIX wieku. Tematykę tę podejmowali tacy uczeni jak Joachim Lelewel, Łukasz Gołębiowski, Julian Bartoszewicz, Henryk Schmitt, Władysław Smoleński, Antoni Małecki, Kazimierz Chodynicki, Marceli Handelsman, czy Jan Adamus. Trzeba jednak przyznać, że przed 1945 rokiem analizy dotyczące historii historiografii wyjątkowo były traktowane przez środowisko uczonych jako odrębna subdyscyplina nauki, powszechnie uważano je za element warsztatu badawczego. Każdy przyjmował jako oczywistość obowiązek zebrania możliwie kompletnej dotychczasowej literatury przedmiotu, potrzebę oceny jej merytorycznej wartości. Wszelkie więc zestawienia bibliograficzne oraz krótkie omówienia zawartości były cenione głównie jako element erudycji uczonego. Nie rozumiano potrzeby odrębnych badań nad historią historiografii. Dla większości bowiem była ona jedynie mechanicznym zestawieniem dotychczasowego dorobku. Działo się tak dlatego, że zgodnie z przekonaniem zdecydowanej większości uczonych począwszy od XIX aż do pierwszej połowy XX wieku nie dostrzegano iż nauka nie jest wolna od wpływów kulturowych, społeczno- ekonomicznych, politycznych. Uważano raczej, że nowe ustalenia w historii miały być zależne jedynie od umiejętności posługiwania się określoną metodą badawczą i od indywidualnych zdolności uczonego' Przy takim rozumieniu procesu poznawania i badania przeszłości historia historiografii mogła być jedynie zbiorem streszczeń dotychczasowych naukowych dokonań. Tak właśnie przedstawiono prace polskich uczonych za lata 1887 do 1937 w jubileuszowym, 50 tomie „Kwartalnika Historycznego”. Niestety tak samo opracowano dokonania historyków w setnym numerze kwartalnika z 1987 roku.

Podobny charakter miała zdecydowana większość drukowanych do II wojny światowej artykułów pisanych z okazji długoletniej pracy lub w związku ze śmiercią uczonego. Zwyczajowo autorzy takich opracowań przestrzegli zasady, że o jubilacie lub o zmarłym można mówić „tylko dobrze albo wcale”. W takich okolicznościach krytycy honorowo milczeli a uczniowie wspominanych uczonych ze wszystkich sił zabiegali o utrwalenie u potomnych jak najlepszego sądu o swych nauczycielach i mistrzach. Najczęściej taki charakter miały omówienia sylwetek uczonych. Trudno było traktować je jako naukowe. s. 8-9.

M. H. Serejski, Przeszłość a teraźniejszość. Studia i szkice historiograficzne, Wrocław-Warszawa-Kraków 1965, 
Zdecydowanie inaczej postrzegał historię historiografii w dobie II Rzeczypospolitej w środowisku warszawskim Marceli Handelsman, profesor Uniwersytetu Warszawskiego, mediewista i badacz dziejów nowożytnych, ale także autor Historyki, pierwszego polskiego podręcznika o „zasadach metodologii i teorii poznania historycznego". Warto przypomnieć, że na około 350 publikacji $30 \mathrm{z}$ nich autor ten poświęcił zagadnieniom metodologiczno-historiograficznym. Równie ważne dla rozwoju historii historiografii jako odrębnej dyscypliny naukowej były prowadzone przez niego zajęcia dydaktyczne. Wysoki poziom zarówno wykładów jak i seminariów magisterskich (merowińskie i karolińskie) oraz doktorskiego, przyciągał studentów, którzy później często poświęcali się pracy naukowej². Handelsman uczył ich wszechstronnej, krytycznej analizy materiałów źródłowych oraz równie wnikliwego rozbioru treści i zrozumienia okoliczności powstawania naukowej literatury przedmiotu. Zwracał uwagę na stosowaną przez historyków praktykę badawczą i jej uwarunkowania. Podkreślał, że to właśnie praktyka, czyli tworzone syntezy, monografie i artykuły, zakodowane w nich style rozumienia i interpretacji przeszłości, decydowały o kształcie uprawianej metodologii ${ }^{3}$. Dlatego rozszyfrowywaniu kodów kulturowych, ukrytych sensów i motywacji pozanaukowych, poświęcał wiele miejsca na swych seminariach. Tak wspominał zajęcia swego mistrza Aleksander Gieysztor:

lubił interpretować teksty, używając przy tym obok erudycji zdrowego rozsądku, [...] uczył szukać bezpośredniego i dalszego kontekstu zdarzeń i zjawisk, wrysowywać je od razu i roboczo w kontur procesów społecznych i politycznych, sprawdzać następnie ich miejsce pod wplywem nowych ustaleń. Domagał się szerokiej kultury historycznej od swych seminarzystów i pomagał wydatnie w jej zdobywaniu.

Gieysztor opisał także jak na prowadzonym w drugiej połowie lat trzydziestych XX wieku seminarium Handelsman zwracał uwagę na coraz częstsze kłamstwa historiografii niemieckiej, ulegającej presji totalitarnej, hitlerowskiej ideologii. Prowadząc zajęcia podkreślał, że na tle faszyzującej Europy wzrasta wartość polskiej historiografii, dystansującej się od skrajnych, fałszywych przedstawień i interpretacji. Gieysztor wspominal, że Hamdelsman: „seminarium swoje poświęcił między innymi rozpatrzeniu współczesnej historiografii niemieckiej, która właśnie podjęła się zawłaszczenia

2 Uczniami Handelsmana byli między innymi: Stanisław Arnold, Aleksander Gieysztor, Henryk Jabłoński, Stefan Kieniewicz, Aleksander Krasuski, Czesław Leśniewski, Witold Łukaszewicz, Marian Małowist, Tadeusz Manteuffel, Gryzelda Missalowa, Wanda Moszczeńska, Henryk Paszkiewicz, Irena Pietrzak-Pawłowska, Stanisław Płoski, Ryszard Przelaskowski, Marian Henryk Serejski, Ludwik Widerszal, Helena Więckowska, Janusz Woliński, Mieczysław Żywczyński.

3 J. Dutkiewicz, Seminarium w świetle jego papierów, „Zeszyty Naukowe UŁ. Seria I” z. 36, 1964, s. 133-161. 
Karola Wielkiego; zebrał te debiuty krytyczne nadając całości tytuł Karolus Magnus czy Karl der Grosse i w ten sposób pomógł czytelnikowi polskiemu w rozumieniu epoki karolińskiej jako kolebki narodów Europy średniowiecznej, której cechy szczególnie nie są uchwytne z pozycji nacjonalizmu XX wieku”" .

Analizy społeczno-politycznych uwarunkowań nauki historycznej wplywów świata zewnętrznego na historyka Handelsman w sposób uporządkowany przedstawił w Historyce. Na jej kartach, podobnie jak w czasie zajęć praktycznych ze studentami, duży nacisk kładł na wszechstronną analizę prac historiograficznych równolegle z podejmowanymi badaniami i krytyką źródeł. Warszawski historyk wskazywał na konieczność stosowania w trakcie analizy pięciu kryteriów wyjaśniających. Pierwsze z nich to kryterium ontologiczne, czyli konieczność zestawienia tekstu historycznego $\mathrm{z}$ rozumieniem przez autora teorii bytu. Ta bowiem warunkowała określone rozumienie świata, które z kolei determinowało narrację i opis rzeczywistości historycznej. Drugie kryterium to kryterium epistemologiczne, czyli konieczność rozpoznania w analizowanym dziele jak jego autor rozumiał teorię poznania. Handelsman odróżniał przedmiot poznania i badania historycznego. To rozróżnienie pozwalało na podkreślenie wpływów czynników środowiskowych na sposób opisu rzeczywistości historycznej. W konsekwencji podkreślona została ważna rola historyka historiografii, który powinien zwracać baczną uwagę na okoliczności i warunki w jakich powstawał tekst historyczny. Trzecie kryterium analizy tekstu Handelsman nazwał metodologicznym. Polegać miało ono na rozpracowaniu praktyki procedur badawczych, które determinowały selekcję faktów. Podkreślał, że procedura opisania przeszłości zależy od indywidualnych predyspozycji historyka, jego umiejętności „wczucia się” w minioną epokę, od jej „zrozumienia” a oparta powinna być na intuicji wynikającej z wiedzy poza źródłowej. Na koniec warszawski historyk upominał się o analizę historiograficzną i historiologiczną tekstu historycznego (czwarte i piąte kryterium). Poziom historiograficzny miał dotyczyć analizy stanu aktualnego i przeszłego piśmiennictwa historycznego. Chodziło o stwierdzenie stanu wiedzy i obszarów nierozpoznanych. Bardzo ciekawe i do dzisiaj inspirujące dla współczesnych historyków historiografii są zalecenia Handelsmana analizy na tzw. poziomie historiologicznym. Pod tym pojęciem rozumiał on potrzebę refleksji nad społecznymi funkcjami historii oraz edukacji historycznej. Zwracał uwagę, że uprawianie nauki o przeszłości zaspokaja potrzeby indywidualne uczonego, ale też czyni zadość wymaganiom stawianym przez dotychczasowy rozwój nauki, a ostatecznie rozwiązuje zagadnienia, których wymaga potrzeba zbiorowości. Historyk analizując dane opracowanie powinien mieć świadomość, że powstało

4 A Gieysztor, Postowie, [w:] M. Handelsman, Średniowiecze polskie i powszechne. Wybór pism, Warszawa 1966, s. 354. 
ono w określonym czasie i miejscu a te także miały wpływ na sposób prezentowania rzeczywistości historycznej. Autorzy niejako byli zmuszeni wydobyć z przeszłości to co interesowało współczesnych, odpowiedzieć na pytania ważne w danym miejscu i czasie. Autor Historyki pisał bez ogródek, że twórczość historiograficzna powinna być rozpatrywana jako „system prób rozwiązywania zagadnień nurtujących [współczesne] społeczeństwo lecz przeniesionych przedmiotowo w przeszłość ${ }^{\prime 5}$. Trudno o bardziej lapidarną a jednocześnie trafną formulę wyjaśniającą jaki ma sens i co jest przedmiotem badania historii historiografii.

Wskazane wyżej zasady analizy tekstów historycznych, a szczególnie wpływów współczesnego oglądu rzeczywistości na interpretacje przeszłości, śmiało można traktować jako wytyczne dla rozwoju powojennej historii historiografii. Mimo że warunki funkcjonowania nauki historycznej uległy rewolucyjnym przeobrażeniom, choć wiele szczegółowych rozwiązań i interpretacji proponowanych przez Handelsmana nie mogło być kontynuowanych, to jednak jego ogólna wizja, jak powinny wyglądać i czemu powinny służyć badania nad dziejami myśli historycznej była inspiracją dla historyków doby powojennej. $W$ wielu elementach jest ona aktualna do dnia dzisiejszego.

Obficie czerpał z nauk swego mistrza Marian Henryk Serejski, który wraz ze swym zespołem podjął systematyczne i szeroko zakrojone prace nad dziejami myśli historycznej. Warto podkreślić, że tak dynamiczny rozwój i wzrost znaczenia tej dyscypliny po II wojnie światowej był możliwy dzięki roli jaką komunistyczne władze nowej Polski przypisywały historii historiografii. Oczekiwanie i presja na uczonych aby bezwzględnie potępić dotychczasowy dorobek nauk humanistycznych, wykazać że uczeni służyli interesom klas posiadających, aby ukryć prawdę o wyzysku ludzi pracy i nieuchronnie zbliżającej się rewolucji, spowodowała że historycy historiografii służyli ideologii marksistowskiej i legitymizowali komunistyczne rządy w dobie PRL. Jerzy Maternicki w latach siedemdziesiątych XX wieku pisał:

...w zakresie historii historiografii po 1945 roku [... ] niewątpliwie jednym z najważniejszych [czynników] był przełom w naszym życiu społeczno-politycznym wyrażający się w powstaniu Polski Ludowej i wkroczeniu jej na drogę socjalistycznego rozwoju. Nowa Polska [...] musiała dokonać gruntownego przewartościowania tradycji historycznych. Wymagało to m.in. przeprowadzenia rachunku z naukowym zapleczem tych tradycji, a więc $\mathrm{z}$ dotychczasową historiografią.

5 T. Pawelec, Myśl metodologiczna Marcelego Handelsmana, Lublin 1994, s. 94-99. 


\section{I dalej czytamy:}

chodziło o wybór tych postaci i szkół historycznych, do których można było nawiązywać w nowych warunkach i wykorzystać w toczącej się aktualnie walce ideologicznej. Tłumaczy to preferencję dla zagadnień ideologicznych widoczną w pracach z zakresu historii historiografii opublikowanych w pierwszym dziesięcioleciu Polski Ludowej. [...] Badania historiograficzne odegrały ważną rolę jako swego rodzaju oręż w walce o marksistowski kształt historiografii polskiej ${ }^{6}$

Uwzględniając przez redakcję ramy tego artykułu (ograniczenie tematu do środowiska Instytutu Historii PAN w Warszawie) warto krótko podjąć problem w jaki sposób podzielić zasługi rozwoju historii historiografii między ośrodek warszawski i łódzki. Wbrew temu co sugeruje tekst Rafała Stobieckiego trudno o jednoznaczne rozstrzygnięcia ${ }^{7}$. Dla Mariana Henryka Serejskiego Łódź była miejscem zamieszkania i pracy na uniwersytecie niecałe 20 lat. Wiele wskazuje na to, że był on związany emocjonalnie z Warszawą, z którą zawodowo nie tracił kontaktu przez całe życie, i w której mieszkał 58 lat. Serejski urodził się w Warszawie, tu zdał maturę, studiował, pracowal jako nauczyciel a później w Wojskowym Biurze Historycznym; w 1938 uzyskał na UW habilitację. Po wojnie wobec zniszczenia stolicy, zatrudnił się na Uniwersytecie Łódzkim, gdzie jako profesor nadzwyczajny a potem zwyczajny był kierownikiem Zakładu Historii Społecznej Starożytności i Średniowiecza a później Katedry Historii Powszechnej. Jednak kierownikiem Zakładu Historii Historiografii był w Instytucie Historii PAN w Warszawie od 1953 do 1968 roku, z Uniwersytetem Łódzkim rozstał się w 1965 roku i wtedy od razu przeprowadził się do Warszawy. Był także przewodniczącym działającej w Warszawie przy IH PAN Komisji Historii Historiografii, oraz brał udział w posiedzeniach Zakładu Historii Nauki i Techniki w warszawskim Instytucie Historii Nauki PAN ${ }^{8}$.

Także zawodowo bardziej z Warszawą, a w mniejszym stopniu z Łodzią, związany był Andrzej Feliks Grabski, który zaraz po skończeniu studiów w 1955 roku został zatrudniony w IH PAN gdzie pracował do 1986 roku. Doktorat bronił na UŁ ale jako mediewista (1962). Jednak to w IH PAN złożył habilitację (1968), otrzymał tytuł

6 J. Maternicki, Narodziny polskiej historii historiografii (1945-1956), [w:] tegoż, Kultura historyczna dawna i współczesna, Warszawa 1979, s. 308.

7 R. Stobiecki, Historia historiografii. Studium z dziejów tożsamości dyscypliny na przykładzie ośrodka łódzkiego," Historia@Teoria”nr 2017/1 (3), s 110-111.

8 J. Maternicki, Marian Henryk Serejski (1897-1975), [w:] Historycy warszawscy ostatnich dwóch stuleci, Warszawa 1986, s. 377-395; A. Wierzbicki, Marian Henryk Serejski jako animator polskiej historii historiografii po II wojnie światowej, [w: ] Historia historiografii i metodologia historii w Polsce i na Ukrainie, red. J. Maternicki, J. Pisulińska, L. Zaszkilniaka, Rzeszów 2015, s. 37-50. 
naukowy profesora zwyczajnego (1988), kierował pracownią Dziejów Myśli Społecznej i Politycznej i co najważniejsze będąc zatrudniony w Warszawie napisał swe najważniejsze prace. Mieszkał w Łodzi, ale jako historyk historiografii funkcjonował w warszawskim środowisku naukowym, z łódzkim środowiskiem historyków do połowy lat osiemdziesiątych nie miał kontaktu' ${ }^{9}$. Dopiero w 1986 roku został kierownikiem Katedry Historii Historiografii w Instytucie Historii UŁ gdzie pracował do śmierci w $2000 \mathrm{roku}^{10}$. Rafał Stobiecki bez wahania pisze o Serejskim i Grabskim jako o historykach łódzkich ${ }^{11}$. W świetle wyżej przedstawionych faktów taka kwalifikacja budzi poważne zastrzeżenia.

Nie ma natomiast żadnych wątpliwości, że warszawskim historykiem, choć urodzonym w Krakowie, jest Andrzej Wierzbicki ${ }^{12}$. Całe swe życie zawodowe związany z Instytutem Historii PAN, uczeń Andrzeja Feliksa Grabskiego i Mariana Henryka Serejskiego. Inaczej niż jego mistrzowie, karierę naukową rozpoczął od razu jako historyk historiografii, ${ }^{13}$.

Już od samego początku swej kariery naukowej Wierzbicki dał dowód dojrzałych umiejętności badawczych. W napisanej w 1972 roku pracy doktorskiej Naród - państwo w polskiej myśli historycznej dwudziestolecia międzywojennego podjął ważny dla ówczesnego pokolenia problem odbudowy własnego państwa po latach rozbiorów ${ }^{14}$. Książka była prezentacją stylów myślenia ówczesnej inteligencji, które wycisnęły piętno na interpretacjach przeszłości. Była tam manifestacja dojrzałości Polaków do posiadania własnego państwa (tzw. „optymizm historyczny”), ale też i walka polityczna między sanacją i narodową demokracją, które często determinowały ujęcia przeszłości narodu i państwa - uosabianego przez wybitnych monarchów, czy wodzów.

Każdego historyka historiografii w zasadzie w mniejszym stopniu interesuje wartość merytoryczna prac, czy wypowiedzi autorów podejmujących refleksje nad przeszłością, bardziej powinien starać się on opisać czemu służyło, czemu nadal służy

9 Gdy w latach osiemdziesiątych pracował na drugim etacie na Uniwersytecie Łódzkim związany był z politologami, był współtwórcą Międzyuczelnianego Instytutu Nauk Politycznych.

10 J. Kmita, R. Stobiecki, Stownik biograficzny historyków tódzkich, Łódź 2000, s. 39-40.

11 Rafał Stobiecki w artykule zamieszczonym w poprzednim numerze rzetelnie omówił naukowe dokonania H. M. Serejskiego i A. F. Grabskiego z zakresu historii historiografii dlatego w tym tekście pozwalam sobie je pominąć.

12 Warto w tym miejscu wspomnieć zabawną anegdotę opowiedzianą o sobie przez Andrzeja Wierzbickiego. Gdy zdawał egzamin u Aleksandra Gieysztora, ten przeglądając jego indeks, z uśmiechem skomentował rok (1942) i miejsce urodzenia w Krakowie: „rozumiem to była smutna, okupacyjna konieczność”.

13 Andrzej Wierzbicki twierdzil, że opinia jakoby historyk historiografii powinien rozpoczynać swą karierę zawodową od badań mediewistycznych lub nowożytnych czy najnowszych, nie jest zasadna. Powoływał się przy tym na słowa Mariana Henryka Serejskiego, który mówił że żałuje iż od samego początku nie zajął się historią historiografii, a lata poświęcone mediewistyce uznawał za stracone.

14 Książkę z uznaniem komentowano w Radiu Wolna Europa. Nie dawało to spokoju Andrzejowi Feliksowi Grabskiemu, który jako promotor doktoratu obawiał się o ciąg dalszy własnej kariery naukowej. 
podejmowanie wątków historycznych, jak w tym kontekście kształtowała się świadomość historyczna społeczeństwa, w jakim stopniu była ona elementem szeroko rozumianej kultury analizowanego okresu. Dlatego Wierzbicki przewrotnie w swej książce o Konstytucji 3 maja $w$ historiografii polskiej stwierdzał:

zdawać by się mogło, że dwieście lat to dla historyków dostatecznie długa perspektywa, by móc jednoznacznie ocenić jedno z największych wydarzeń w życiu naszego narodu. Okazuje się jednak, że ani upływ czasu, ani idące $\mathrm{z}$ nim w parze doskonalenie metod badawczych, ani w końcu poszerzająca się stale możliwość dostępu do źródeł historycznych, nie zdołały doprowadzić do „zgody powszechnej” na temat Konstytucji 3 Maja [...]. Czytelnika interesuje „końcowy produkt”, „ostateczna” odpowiedź na pytanie „jak to rzeczywiście było"? Rzecz jednak w tym, że tak rozumiany produkt nie istnieje ${ }^{15}$.

Ta obserwacja wynikająca z badań historiografii skłoniła do napisania arcyciekawej książki o losach uwikłanych we współczesne problemy interpretacji historycznych w XIX i XX wieku, do dzisiaj aktualnych.

Trzeba podkreślić umiejętność Wierzbickiego podejmowania tematów istotnych i ważnych zarówno dla dawnych, jak i dla współczesnych pokoleń Polaków. Stąd duża wartość jego książek takich jak: Wschód - Zachód w koncepcjach dziejów Polski (1984), Spór o polską duszę. Z zagadnień charakterologii narodowej w historiografii polskiej XIX i XX wieku (dwa wydania: 1993, 2010), Groźni i wielcy. Polska myśl historyczna XIX i XX wieku wobec rosyjskiej despotii (2001), czy wreszcie Europa w polskiej myśli historycznej i politycznej XIX i XX wieku (2009). Nie ma w wymienionych książkach Wierzbickiego jedynie dokumentacji poglądów na określone tematy historyczne. Znajdujemy w nich opis różnorodnych koncepcji historiozofii narodowej, analizę interpretacji przeszłości odzwierciedlającej współczesne światopoglądowe i ideowo-polityczne przekonania.

W pracy o Wschodzie i Zachodzie Wierzbicki analizuje nie tylko problem poczucia przynależności Polaków do cywilizacji zachodniej ale także, w dobie romantyzmu, do słowiańskiego Wschodu. Autor opisuje dyskutowany w XIX wieku problem «normalności» lub «anomalii» w rozwoju dziejowym Polski. Oceny historyków, choć udokumentowane źródłowo i zgodne z metodologicznymi regułami, bynajmniej nie były pisane według zasady sine ira et studio.

Podejmując problem charakteru narodowego Wierzbicki podkreślał jak manipulowano tym pojęciem, jak wykorzystywano stereotypowe wyobrażenia do aktualnych potrzeb, by zgodnie z własnymi przekonaniami najczęściej «wychwalać naród» tak w XIX, jak i w XX wieku. W drugim rozszerzonym wydaniu książki opisuje on

15 A. Wierzbicki, Konstytucja 3 Maja w historiografii polskiej, Warszawa 1993, s. 5. 
także dyskusje jakie toczono w dobie PRL-u. W konkluzjach swej pracy ostatecznie stwierdza, że brak jest procedur, które pozwalałyby na naukowe rozpoznanie zjawiska nazywanego «charakterem narodowym».

W książce o Europie Wierzbicki stwierdza, iż poczucie europejskości wśród Polaków było jednym z najważniejszych elementów kształtujących naszą świadomość narodową, tak w czasach nowożytnych, jak i współczesnych. Zwraca też uwagę na to jak niejednoznacznie na przestrzeni wieków rozumiano samo pojęcie «europejskości».

Ważną książką Wierzbickiego była monografia Historiografia polska doby romantyzmu (1999) nagrodzona przez Fundację Nauki Polskiej. Jej autor nie tylko opisał wątki historyczne, ale także zwrócił uwagę na kształtujące wyobrażenia o przeszłości wydarzenia społeczne, gospodarcze, nurty filozoficzne i polityczne. Zaprezentował zagmatwane i niejasne struktury nauki, zestawił je z treściami podejmowanych prac, połączył je z życiorysami twórców (pochodzenie społeczne, wykształcenie, uprawiane zawody). Nie pominął panujących wówczas zasad edytorskich, systemu oświaty, dokonań poszczególnych subdyscyplin (historii prawa, sztuki, archeologii). Wszystko to pozwoliło warszawskiemu historykowi odtworzyć panującą $\mathrm{w}$ danym okresie atmosferę intelektualną warunkującą określony styl myślenia i pisania o historii.

Andrzej Wierzbicki jest twórcą i redaktorem naukowym serii wydawniczej przekształconej ostatnio w rocznik, wydawany przez Instytut Historii PAN, Klio Polska. Studia i materiały z dziejów historiografii polskiej XIX-XX w. zapoczątkowanej w 2004 roku. Do tej pory ukazało się osiem tomów tego wydawnictwa, dziewiąty jest aktualnie w druku. Na łamach pisma publikują autorzy badający problemy historii historiografii z całego kraju.

W kontekście tego co napisałem powyżej, nie dziwi opinia Jerzego Jedlickiego, który w recenzji z 2011 roku, z drugiego wydania Sporów o polska duszę nazwał Andrzeja Wierzbickiego „najwybitniejszym żyjącym historykiem historiografii” ${ }^{\text {. }}$.

Niestety na przestrzeni lat w Instytucie Historii PAN trudno mówić o stabilizacji organizacyjnej dla badań historii historiografii. Po śmierci Mariana Henryka Serejskiego zlikwidowano prowadzony przez niego zakład. Jego współpracownicy (Andrzej Feliks Grabski i Andrzej Wierzbicki) zostali włączeni do Pracowni Dziejów Kultury, kierowanej przez Janusza Tazbira. Szczęśliwie jej kierownik dał pełną autonomię podległym sobie historykom historiografii, którzy mogli między innymi kontynuować prace związane z podjętym przez Ryszarda Przelaskowskiego Vademecum historiografii polskiej. Miało ono objąć okres od XVIII do XX wieku, niestety

16 J. Jedlicki, Cały naród jak jeden mąż?, „Nowe Książki” 2011, nr 5, s. 10. 
z przyczyn niezależnych od wydawców, prace te zostały przerwane ${ }^{17}$. Od 1974 roku została utworzona w IH PAN Pracownia Dziejów Myśli Społecznej i Struktur Politycznych, której kierownikiem został Andrzej Feliks Grabski. Później kierownictwo pracowni przejęła Monika Senkowska-Gluck (po zmianie nazwiska Monika Haman) a od 1992 roku Andrzej Wierzbicki. Warto w tym miejscu wspomnieć, że większość członków Rady Naukowe IH PAN nie wyraziła zgody aby tworzona w 1974 roku pracownia nosiła nazwę „, historii historiografii”. Jak argumentowano, taka nazwa obniżałaby prestiż prowadzonych w niej badań. Pracownia została zlikwidowana wraz z przejściem na emeryturę jej kierownika, a dotychczasowi pracownicy (Zbigniew Romek i Marcin Wolniewicz) oraz Andrzej Wierzbicki funkcjonują od 2013 roku w ramach Zakładu Historii Idei i Dziejów Inteligencji XIX-XX wieku, kierowanego przez Macieja Janowskiego. Szczęśliwie, dzięki życzliwości Janowskiego grupa badaczy historii historiografii, posiada autonomię i odbywa systematyczne spotkania, których uczestnikami są osoby pracujące w IH PAN i poza nim: Andrzej Wierzbicki (IH PAN), Maciej Górny (IH PAN), Adam Kożuchowski (IH PAN), Zbigniew Romek (IH PAN), Marcin Wolniewicz (IH PAN), Katarzyna Blachowska (IH UW), Tomasz Ochinowski (Wydz. Zarządzania UW), Tadeusz Paweł Rutkowski (IH UW), Jan Szumski (IHN PAN i UKSW).

17 Ukazała się tylko: Historiografia polska $w$ dobie pozytywizmu (1865-1900). Kompendium dokumentacyjne, opracował zespół pod red. R. Przelaskowskiego, Warszawa 1968. Zob. też: R. Przelaskowski, Projekt opracowania Vademecum dziejów historii historiografii polskiej, „Studia Źródłoznawcze. Commentationes” t. IX, 1964, s. 137-142. 